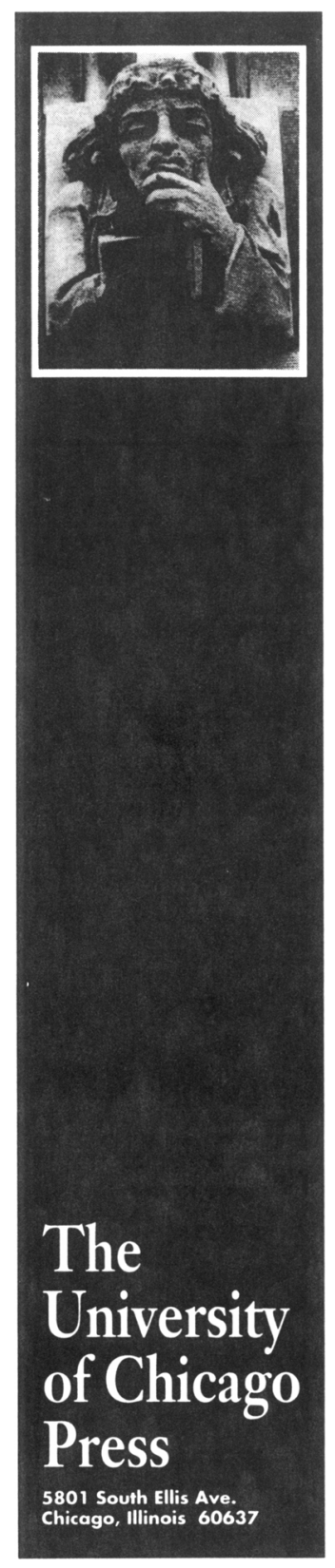

\title{
Acts of Hope
}

Creating Authority in Literature, Law, and Politics James Boyd White

"A subtle and eloquent account of the ways in which texts involve their reader in the building of communities. This book compels admiration on many levels."-Martha C. Nussbaum, Brown University

Cloth $\$ 27.50368$ pages

\section{Imperfect Alternatives}

Choosing Institutions in Law, Economics, and Public Policy

\section{Neil K. Komesar}

"Komesar's discussion is perceptive and instructive. This is a valuable work which should be taken seriously by legal scholars, particularly those in law and economics."-R.H. Coase, Winner of the 1991 Nobel Prize in Economics

Cloth $\$ 34.95304$ pages

\section{Discourse and Destruction}

The City of Philadelphia versus MOVE

\section{Robin Wagner-Pacifici}

Wagner-Pacifici examines how the struggle in the 1980s between the city of Philadelphia and the radical group MOVE went from memos and meetings to tear gas and bombs.

"Fascinating. This book encourages the reader to examine the discourse surrounding social violence in ways that are both more critical and more systematic."-Wendy Griswold, University of Chicago

Paper \$12.95 192 pages Cloth edition available

\section{Now in paper}

\section{Images of a Free Press}

\section{Lee C. Bollinger}

"Images of a Free Press builds on Dean Bollinger's previous work to make an intricate, ambitious, provocative, and important contribution to the literature on the legal status of the modern press." -Lili Levi, Cornell Law Review

Paper $\$ 14.95217$ pages 


\section{mententan American University Presses Directory 1993-1994}

A $s$ an introduction and guide to the world of university presses, this directory is an essential A reference and resource for anyone who is, or wants to be, involved in scholarly publishing. The Association of American University Presses has for over fifty years worked to encourage the dissemination of scholarly research and ideas. Today the 114 members of the AAUP annually publish nearly 9,000 books and more than 800 periodicals.

Among its useful features are:

- Information on 114 university presses in the U.S., Canada, and overseas

- Complete addresses, phone and fax numbers

- Names and responsibilities of key staff

- Subject area guide with 136 categories, indicating which presses publish in a given area

- Advice for authors on the submission of manuscripts

\section{Distributed for the Association of American Lniversity Presses \\ The University of Chicago Press}

Please send me 1993-94 AAUP Directory (paper) at \$14.95 each (ISBN 0-945103-07-7)

Total order $\$$

Sales tax (IL addresses $8 \%$ addl.) \$

Shipping and Handling:

Check or Money Order attached. Phone:

Credit Card No. Exp. Date:

Signature:

Address:

City/State/Zip:

Mail your order to:

The University of Chicago Press 5801 South Ellis

Chicago, IL 60637

Shipping and handling. Please add $\$ 2.00$ for the first book and $\$ .75$ for each additional book. Customers outside the USA should add $\$ 3.00$ for the first book and

$\$ .75$ for each additional book.

Purchase orders and individual orders charged to Visa and MasterCard may be sent by Fax to 312-660-2235

SA1010 


\section{O N O G R A P H S}

\section{of the Society for Research in Child Development}

\section{Testifying in Criminal Court: Emotional Effects on Child Sexual Assault Victims Gail S. Goodman et al.}

"Has immediate, far-reaching, and positive implications for child abuse litigation. ... Forms the bench mark by which to evaluate future research." --John E. B. Myers

Increased reports of child sexual abuse are bringing unprecedented numbers of children into contact with the criminal justice system, raising fears that victims will be further harmed in the process. In this study, the adverse effects of testifying in court were examined among 218 children. The results show how testifying in the traditional manner interferes with children's ability to answer questions, thus undermining the very purpose of a trial: discovery of truth.

$\$ 14.00$ 0-226-30323-3 (57:5, serial no. 229, 1992)

Published for the Society for Research in Child Development by

\section{The University of Chicago Press}

Journals Division, P.O. Box 37005, Chicago, IL 60637

Fax 312/753-0811 


\section{Paper Edition Now Available}

\section{BEYOND THE LA W Crime in Complex Organizations}

Edited by Michael Tonry and Albert J. Reiss, Jr.

This newest volume in the Crime and Justice series focuses on the latest research and commentary on criminal misconduct occurring in U.S. corporations and government agencies, with special emphasis on savings and loan fraud, insider trading, nursing homes, environmental pollution, and other forms of "white collar crime."

Leading experts from a variety of disciplines investigate these antisocial and unlawful behaviors, and further explore the roles of self-regulation, administrative regulation, and civil and criminal sanctions in shaping organizational behavior.

Organizational Crime, Albert J. Reiss, Jr., and Michael Tonry

The Nursing Home Industry, John Braithwaite

Insider Trading, Nancy Reichman

Industrial Water Pollution, Peter Cleary Yeager

The Cartage Industry in New York, Peter Reuter

The Savings and Loan Industry, Henry N. Pontell and Kitty Calavita

Crime, Justice, and the Savings and Loan Crisis, Franklin E. Zimring and Gordon Hawkins

Michael Tonry is Marvin J. Sonosky Professor of Law and Public Policy at the University of Minnesota. Albert J. Reiss, Jr. is William Graham Sumner Professor of Sociology and Lecturer in Law at Yale University.

$\begin{array}{llll}1993 \quad 320 \text { pp. } & \text { Cloth } & \$ 35.00 & \text { ISBN: 0-226-80821-1 } \\ & \text { Paper } & \$ 19.95 & \text { ISBN: 0-226-80823-8 }\end{array}$

Beyond the Law is Volume 18 of the Crime and Justice series, edited by Michael Tonry.

Order through your bookstore or directly from

The University of Chicago Press

11030 S. Langley Ave., Chicago, IL 60628

Or call: (312) 568-1550 


\section{NEW FROM CRITICAL INQUIRY BOOKS}

\section{QUESTIONS OF EVIDENCE}

\section{Proof, Practice, and Persuasion across the Disciplines}

James Chandler, Arnold I. Davidson, and Harry Harootunian, editors

Surprisingly little attention has been directed toward the central concern of what constitutes evidence in research and scholarship. Questions of Evidence seeks to fill that gap by bringing together thirteen major essays by leading scholars and researchers in multiple fields across the sciences and humanities. Each essay (originally published in Critical Inquiry) is accompanied by a never-before-published critical response and a rejoinder by the author of the original essay.

\section{CONTENTS}

Terry Castle, Contagious Folly: An Adventure and Its Skeptics (response by Françoise Meltzer)

Simon Schaffer, Self Evidence (response by Lawrence Rothfield)

Eve Kosofsky Sedgwick, Jane Austen and the Masturbating Girl (response by Lauren Berlant)

Barbara Herrnstein Smith, Belief and Resistance: A Symmetrical Account (response by Robert Richards)

Mark Kelman, Reasonable Evidence of Reasonableness (response by Cass R. Sunstein)

Donald Preziosi, The Question of Art History (response by Joel Snyder)

Lorraine Daston, Marvelous Facts and Miraculous Evidence in Early Modern Europe (response by James Chandler)

Carlo Ginzburg, Checking the Evidence: The Judge and the Historian (response by Arnold I. Davidson)

Pierre Vidal-Naquet, Atlantis and the Nations (response by Elizabeth Helsinger)

Joan W. Scott, The Evidence of Experience (response by Thomas C. Holt)

Mary Poovey, Figures of Arithmetic, Figures of Speech: The Discourse of Statistics (response by Harry Harootunian)

Ian Hacking, Two Souls in One Body (response by Jean Comaroff)

R. C. Lewontin, Facts and the Factitious in Natural Sciences (response by William Wimsatt)

James Chandler is professor of English at the University of Chicago. Arnold I. Davidson is professor of philosophy at the University of Chicago. Harry Harootunian is the Max Palevsky Professor of East Asian Languages and Civilizations and History at the University of Chicago.

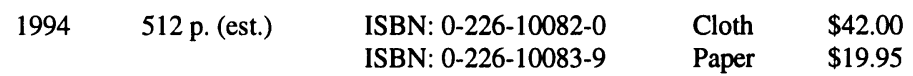

Available at bookstores or from

The University of Chicago Press

11030 S. Langley Ave., Chicago, IL 60628

Or call: (312) 568-1550 


\section{Journals from The University of Chicago Press}

At the forefront of academic publishing for a century, the University of Chicago Press brings you the highest standards of scholarship.

\section{Social Sciences}

Adolescent Psychiatry

American Journal of Sociology

Child Development

Child Development Abstracts and Bibliography

Crime and Justice

Current Anthropology

Economic Development and Cultural Change

International Annals of Adolescent Psychiatry Isis

Journal of British Studies

The Journal of Business

Journal of Consumer Research

Journal of the History of Sexuality

Journal of Labor Economics

The Journal of Law \& Economics

The Journal of Legal Studies

The Journal of Modern History

Journal of Political Economy

Law \& Social Inquiry

The Library Quarterly

Monographs of the Society for Research in Child Development

Ocean Yearbook

Osiris

Perspectives on Science: Historical,

Philosophical, Social

Public Opinion Quarterly

Signs: Journal of Women in Culture and Society

Social Service Review

The Supreme Court Review

Technology and Culture

\section{Humanities}

Classical Philology

Critical Inquiry
Ethics: An International Journal of Social, Political, and Legal Philosophy

History of Religions

International Journal of American

Linguistics

Journal of Near Eastern Studies

The Journal of Religion

Modern Philology

Public Culture

Winterthur Portfolio: A Journal of

American Material Culture

\section{Education}

American Journal of Education

Comparative Education Review

The Elementary School Journal

Biological and Medical Sciences

The American Journal of Human Genetics

The American Naturalist

International Journal of Plant Sciences (formerly Botanical Gazette)

Clinical Infectious Diseases (formerly

Reviews of Infectious Diseases)

The Journal of Infectious Diseases

Molecular Biology and Evolution

Perspectives in Biology and Medicine

Physiological Zoology

The Quarterly Review of Biology

Physical Sciences

The Astrophysical Journal

The Astrophysical Journal Supplement Series

The Journal of Geology

Distributed by the University of

Chicago Press

Metropolitan Museum Journal

For information about individual journals, write to Sandra Willis, Subscription Fulfillment, The University of Chicago Press, Journals Division, P.O. Box 37005, Chicago, IL 60637. Fax (312) 753-0811. 


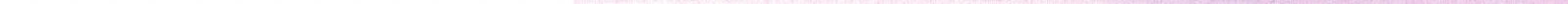




\section{Law \& Social Inquiry}

\section{Enter a new subscription and save $25 \%$ !}

$\begin{array}{lll}\square \text { Individuals } & \text { New } & \text { Renewal } \\ \square \text { Institutions } & \square \$ 27.00 \text { (F) } & \square \$ 36.00 \\ \square \text { Academics* } & \square 44.25(\mathrm{~F}) & \square 9.00 \\ 21.75(\mathrm{~F}) & \square 29.00\end{array}$

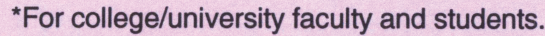

Outside USA: please add $\$ 6$ for postage.

Canadians: please add $7 \%$ GST.

$\square$ Back issues: remaining issues (vol. 14-18) at $50 \%$ off:

$\square \$ 100.00$ Individuals $\square \$ 157.50$ Institutions

Outside USA: please add $75 \varnothing$ per issue for postage.

Canadians: please add $7 \%$ GST.

\section{Payment Options \\ Orders must include payment in U.S. dollars. \\ Fax credit card orders to (312) 753-0811.}

\section{$\square$ Charge $\square$ MasterCard $\square$ visa}

Expiration date

Account no.

Signature

Phone number

Check enclosed (in U.S. dollars drawn from a U.S. bank, payable to the journal)

Name

Address

City/State/Zip/Country

For special savings on two and three year rates, please direct inquiries to address listed below.

Please send your order to The University of Chicago Press, Journals Division, P.O. Box 37005, Chicago, IL 60637 USA.

\section{Law \& Social Inquiry}

\section{Enter a new subscription and save $25 \%$ !}

$\begin{array}{lll} & \text { New } & \text { Renewal } \\ \square \text { Individuals } & \square \$ 27.00 \text { (F) } & \square 36.00 \\ \square \text { Institutions } & \square 44.25 \text { (F) } & \square 9.00 \\ \square \text { Academics* } & \square 21.75 \text { (F) } & \square 29.00\end{array}$

*For college/university faculty and students.

Outside USA: please add $\$ 6$ for postage.

Canadians: please add $7 \%$ GST.

Back issues: remaining issues (vols. 14-18) at $50 \%$ off:

$\square 100.00$ Individuals $\square \$ 157.50$ Institutions

Outside USA: please add $75 \varnothing$ per issue for postage.

Canadians: please add $7 \%$ GST.

\section{Payment Options \\ Orders must include payment in U.S. dollars. \\ Fax credit card orders to (312) 753-0811.}

\section{$\square$ Charge $\square$ MasterCard $\square$ visa}

Expiration date

Account no.

Signature

Phone number

Check enclosed (in U.S. dollars drawn from a U.S. bank, payable to the journal)

Name

Address

City/State/Zip /Country

For special savings on two and three year rates, please direct inquiries to address listed below.

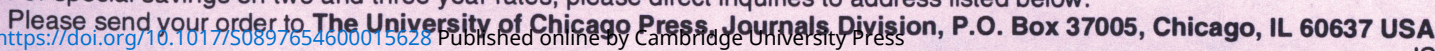




\section{American Bar Foundation}

\section{BOARD OF DIRECTORS}

President, John C. Deacon, of the Arkansas Bar - Vice-President, Robert MacCrate, of the New York Bar - Secretary, Hon. Jerome Farris, United States Court of Appeals, Ninth Circuit • Treasurer, Kenneth J. Burns, Jr., of the Illinois Bar

Jacqueline Allee, St. Thomas University School of Law • Robert W. Bennett, Northwestern University School of Law - Brooksley E. Born, of the District of Columbia Bar - Daniel Gourash, of the Ohio Bar - James W. Hewitt, of the Nebraska Bar - Carrie Menkel-Meadow, University of California at Los Angeles School of Law - Robert A. Stein, Executive Director of the American Bar Association • Cathy S. Wright, of the Alabama Bar

ex officio:

George E. Bushnell, Jr., President, American Bar Association • Roberta Cooper Ramo, President-Elect, American Bar Association • Philip S. Anderson, Chairman, House of Delegates, American Bar Association - M. Peter Moser, Treasurer, American Bar Association • Bert H. Early, President, American Bar Endowment • James W. Hewitt, Chair, The Fellows of the American Bar Foundation • Martha S. Tucker, Vice-Chair, The Fellows of the American Bar Foundation • Herbert D. Sledd, Secretary, The Fellows of the American Bar Foundation

\section{OFFICERS}

Bryant G. Garth, Director

Joanne Martin, Assistant Director
Anne Tatalovich, Assistant Director

Hayden C. Flor, Jr., Financial Officer

\section{RESEARCH FELLOWS}

Lori B. Andrews, J.D. Yale University

Jonathan D. Casper, Ph.D. Yale University

John L. Comaroff, Ph.D. University of London

Stephen Daniels, Ph.D. University of Wisconsin

Shari S. Diamond, Ph.D. Northwestern University;

J.D. University of Chicago

John J. Donohue, J.D. Harvard University;

Ph.D. Yale University

William L. F. Felstiner, J.D. Yale University

Bryant G. Garth, J.D. Stanford University; Ph.D.

European University Institute

Janet A. Gilboy, Ph.D. Northwestern University

Terence C. Halliday, Ph.D. University of Chicago

James J. Heckman, Ph.D. Princeton

Carol A. Heimer, Ph.D. University of Chicago

John P. Heinz, LL.B. Yale University
Karyl A. Kinsey, Ph.D. University of Chicago

E. Allan Lind, Ph.D. University of North Carolina at Chapel Hill

Arthur F. McEvoy, J.D. Stanford University; Ph.D. University of California, San Diego

Elizabeth Mertz, J.D. Northwestern University; Ph.D. Duke University

Robert L. Nelson, J.D., Ph.D. Northwestern University

Robert J. Sampson, Ph.D. State University of New York at Albany

Susan P. Shapiro, Ph.D. Yale University

Peter Siegelman, Ph.D. Yale University

Kent W. Smith, Ph.D. Harvard University

Christopher L. Tomlins, Ph.D. Johns Hopkins

Victoria Woeste, Ph.D. University of California, Berkeley

\section{VISITING RESEARCH FELLOWS}

Thomas Joseph Davis, Professor of History and African American Studies, State University of New York at Buffalo

Kriss Drass, Professor of Sociology, University of Nevada, Las Vegas

\section{LIAISON RESEARCH SERVICES PROGRAM}

Joanne Martin, M.M. Northwestern University, J.D. Loyola University

Barbara A. Curran, LL.B. University of Connecticut, LL.M. Yale University 


\section{Law \& Social Inquiry}

\section{Volume 19, Number 3, Summer 1994}

\section{ARTICLES}

Genealogy and Jurisprudence: Nietzsche, Nihilism, and the Social

Scientification of Law

MARIANNE CONSTABLE

Commentaries

Passionate Kisses?

KENNETH CMIEL

Coming Home

CHRISTINE B. HARRINGTON AND JOHN BRIGHAM

Asking the Right Question

FRANK MUNGER

Leading Law into the Abyss: What (If Anything) Has Sociology

Done to Law?

AUSTIN SARAT

Rejoinder

Thinking Nonsociologically about Sociological Law MARIANNE CONSTABLE

"You Wouldn't Take a Seven-Year-Old and Ask Him All These Questions": Jurors' Use of Practical Reasoning in Supporting Their Arguments

JOHN F. MANZO

\section{REVIEW ESSAYS}

Two Faces of Justice: A Milestone in Quantitative Cross-cultural Research DAVID T. JOHNSON AND SETSUO MIYAZAWA

Interpretation and Validity Assessment in Qualitative Research: The Case of H. W. Perry's Deciding to Decide

HERBERT M. KRITZER

Shaky Grounds: The Case against the Case against Antidiscrimination Laws PETER SIEGELMAN

Heroic Medicine, Physician Autonomy, and Patient Rights LISA R. STAFFEN

Pragmatism and Faith: Selznick's Complex Commonwealth DAVID C. WILLIAMS

Religion, Law, and Contemporary American Culture: Carter and Powell Struggle with the Issues BOOTH FOWLER

\section{BOOK NOTES}

